Proceedings

\title{
Diversity and Status of Small Mammals of Mountainous Range Karakoram and the Western Himalayas in Gilgit-Baltistan, (Pa- kistan) ${ }^{\dagger}$
}

\author{
Abu ul Hassan Faiz*, Ghazal Tariq and Lariab Zahra Faiz \\ * Correspondence: sabulhussan@gmail.com \\ † Presented at the 1st International Electronic Conference on Biological Diversity, Ecology and Evolution, 15- \\ 31 March 2021; Available online: https://bdee2021.sciforum.net/.
}

Citation: Abu ul Hassan Faiz*, Ghazal Tariq and Lariab Zahra Faiz. Diversity and Status of Small Mammals of Mountainous Range Karakoram and the Western Himalayas in Gilgit-Baltistan, (Pakistan). Proceedings 2021, 68, $\mathrm{x}$.

https://doi.org/10.3390/xxxxx

Publisher's Note: MDPI stays neutral with regard to jurisdictional claims in published maps and institutional affiliations.

Copyright: (C) 2021 by the authors Submitted for possible open access publication under the terms and conditions of the Creative Commons Attribution (CC BY) license (http://creativecommons.org/licenses /by/4.0/).

\begin{abstract}
The abundance and community composition of small mammals play a key role as biological indicator for environment health in functioning of any ecosystem. The small mammals serve on second trophic level in food chain and have versatile nature to adopt any habitat (wild to commensal habitat). The present study is conducted in district Gilgit rural areas (Shigar, Khaplu, Kharmang). The study started was conducted from 1 February 2019 to 1july 2019. In experimental design of (6 houses, 3 shops and one farm house), 300 small mammals were trapped during 600 trap nights and 600 traps. Among the captured small mammals were, the house rat (Rattus rattus), house mouse (Mus musculus), Kashmir Field Mouse (Apodemus rusiges), one species of the Kashmir pigmy shrew, (Sorex planiceps) and one species of (Rattus turkistanica).The order of dominance was (Rattus rattus) $30 \%$, followed by mus musculus $23 \%$, followed by apodemus rusigus $20 \%$ Sorex planiceps $17 \%$ and least occurred species was Rattus turkistanica $10 \%$.
\end{abstract}

Keywords: commensal habitat; pigmy shrew

\section{Introduction}

Rodents are an important group of mammals and important components of all of the earth's terrestrial ecosystems due to their predatory and prey behavior (Pardini, 2004) Worldwide distribution of rodents is due to their adaptability to a wide range of habitats , (Grzimek, 2003) and their small size and short breeding cycle with diverse food habits (Wolf and Sherman, 2007).The pattern of distribution of small mammals is influenced by habitat resources such as food, shelter, weather condition (Pradhan and Talmale, 2011). To follow movements of small mammals and monitor social interactions between individuals can be vital to study dynamics of populations and species composition (Duncan 2003). The biology, ecology, and behavior of each species or even of the same species occurring in different environments must be examined carefully to understand population dynamic (Tobin 2004).

The critical importance of mammalian population dynamics is to understand human land use practice by which population trends are known, more than $50 \%$ of species are currently declining (Schipper, 2008). Biological communities are being destroyed due to a plethora of anthropogenic forces (Brooks et al., 2006). A lot of studies on small mammals are present such as mammalian diversity (Faiz et al.2016), small mammalian studies in pothwar plateau (Faiz et al.2014) but The present study is designed with the objective to study the species composition at highland of Himalayas.

Material and methods 


\section{Study area}

Shigar, Khaplu, Kharmang are most beautiful valleys of the district Gilgit, that lie in the north-eastern side of the capital city Gilgit between $35.50^{\circ} \mathrm{N}$ latitude and $74.54^{\circ} \mathrm{E}$ longitude, covering an area of 2340 sq.. $\mathrm{km}$. The area has several mountains, glaciers, peaks, forests, shrub lands, alpine meadows at different elevations.

\section{Trapping of rats}

The trapping was conducted in five study sites, Shigar, Khaplu, Kharmang with GPS readings taken at each site. Locally made metallic snap rat traps $(17 \times 9.5 \mathrm{~cm})$ were used for trapping of rodents in the rural areas. In each village traps were set at two different sites i.e. houses and field. The traps were baited with peanut butter or bread soaked in vegetable oil, depending upon the availability of the local areas. At each site, fixed numbers of traps were set in the evening and were collected early in the following morning and were processed at the spot. In the field, traps were set on the ground along linear transects (trap lines) for four consecutive nights in each selected habitat.

The captured specimen was assigned a number on the tag, along with the relevant information like locality, date of capturing and sex of the animal etc. The specimens were brought to the laboratory of the department of Zoology, Women university of Azad Jammu and Kashmir, for further processing. After taking the body weight (gms) of captured rodents with a spring balance, different measurements like total body length (BL), head and body length (HBL), tail length (TL), ear length (EL), hind foot length (HFL) and the sex of the specimen was recorded to identify the species of the specimen according to Aplin et al., (2003

\section{RESULTS AND DISCUSSION}

Table No.1 Trapping summary.

\begin{tabular}{|c|c|c|c|c|c|c|c|c|}
\hline \multirow[t]{3}{*}{ site } & & \multicolumn{6}{|c|}{ Capture per Night } & \\
\hline & & \multicolumn{7}{|c|}{ Farm houses } \\
\hline & & no. of nights & 1 & 2 & 3 & Total capture & capture rate & \%capture rate \\
\hline Shigar, & 1 & 36 & 7 & 4 & 3 & 14 & 0.39 & 38.9 \\
\hline Khaplu, & 1 & 36 & 8 & 6 & 3 & 17 & 0.47 & 47.2 \\
\hline \multirow[t]{2}{*}{ Kharmang } & 1 & 36 & 9 & 7 & 2 & 18 & 0.50 & 50.0 \\
\hline & & \multicolumn{7}{|c|}{ Shops } \\
\hline Shigar, & 3 & 36 & 15 & 9 & 4 & 28 & 0.78 & 77.8 \\
\hline Khaplu, & 3 & 36 & 13 & 12 & 10 & 35 & 0.97 & 97.2 \\
\hline \multirow[t]{2}{*}{ Kharmang } & 3 & 36 & 14 & 13 & 10 & 37 & 1.03 & 102.8 \\
\hline & & \multicolumn{7}{|c|}{ House Dwelling } \\
\hline Shigar, & 6 & 36 & 16 & 14 & 10 & 40 & 1.11 & 111.1 \\
\hline Khaplu, & 6 & 36 & 17 & 15 & 11 & 43 & 1.19 & 119.4 \\
\hline Kharmang & 6 & 36 & 18 & 9 & 13 & 40 & 1.11 & 111.1 \\
\hline
\end{tabular}

At farm house, the number of animals trapped at study site Shigar, was 14, with six traps and six trapping nights while at study site Khaplu, 17 animals were trapped with same number of traps and traps night. The maximum trapping was done at farm house of Kharmang with 18 animals (Table No.1). The number of animals trapped at study site Shigar at shops trapping, was 28, with six traps and six trapping nights while at study site Khaplu, 35 animals were trapped with same number of traps and traps night. The maximum trapping was done at farm house of Kharmang with 37 animals (Table No.1).At house dwelling, the number of animals trapped at study site Shigar, was 40, with six traps and six trapping nights while at study site Khaplu, 43 animals were trapped with same 
number of traps and traps night. The maximum trapping was done at farm house of Kharmang with 40 animals (Table No.1).

Table No.2.Species composition.

\begin{tabular}{|l|r|r|r|r|r|r|}
\hline Species & male & sub adult & juvenile & female & sub adult & juvenile \\
\hline Rattus rattus & 25 & 15 & 10 & 20 & 15 & 5 \\
\hline Mus musculus & 20 & 10 & 10 & 12 & 13 & 5 \\
\hline Apodemus rusiges & 15 & 10 & 10 & 12 & 10 & 3 \\
\hline Sorex planiceps & 15 & 5 & 6 & 12 & 10 & 2 \\
\hline Rattus turkistanica & 12 & 4 & 1 & 6 & 5 & 2 \\
\hline
\end{tabular}

The (Rattus rattus ) male to female ratio 5 to 4 ,while subadult ratio $(1,1)$ and juvenile ratio is (2.1).The (Mus musculus ) male to female ratio 5 to 3, while subadult ratio $(10,13)$ and juvenile ratio is (2.1).The (Apodemus rusiges) male to female ratio 5 to 4 , while subadult ratio $(1,1)$ and juvenile ratio is (10.3). The (Sorex planiceps ) male to female ratio 5 to 4 , while subadult ratio $(1,2)$ and juvenile ratio is (3.1). The (Rattus turkistanica) male to female ratio 2 to 1 ,while subadult ratio $(2,3)$ and juvenile ratio is (2.1) Table 2.

\section{Estimated population of (Rattus rattus).}

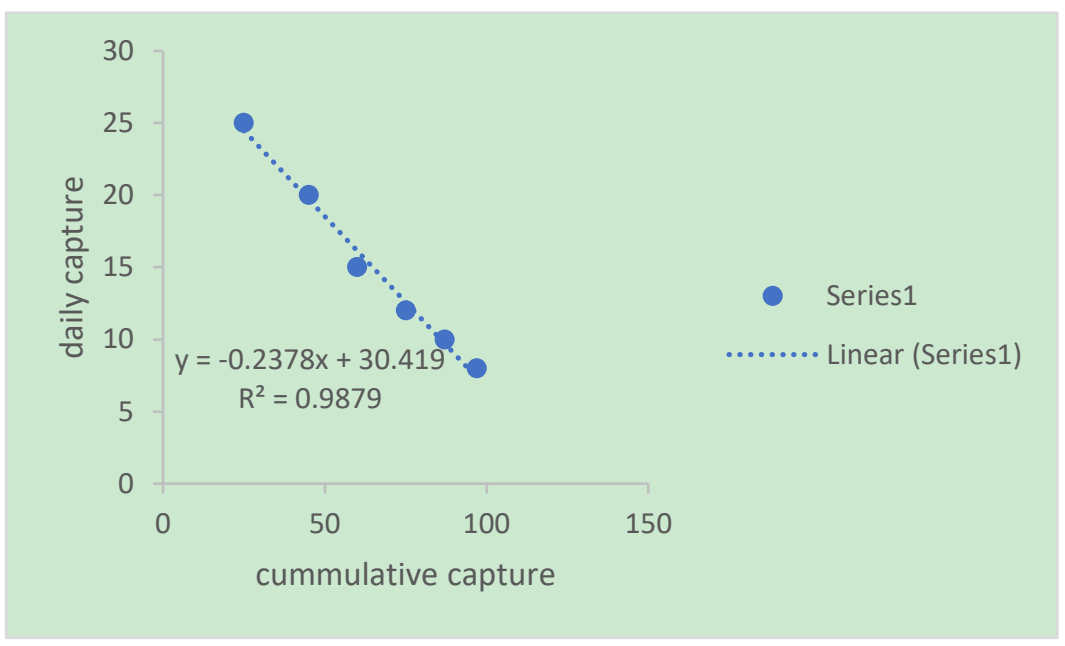

Fig. No.1 .Estimated population of (Rattus rattus)

The estimated population of (Rattus rattus) by regression analysis was 100 and minimum was 30 (Fig.

1). 


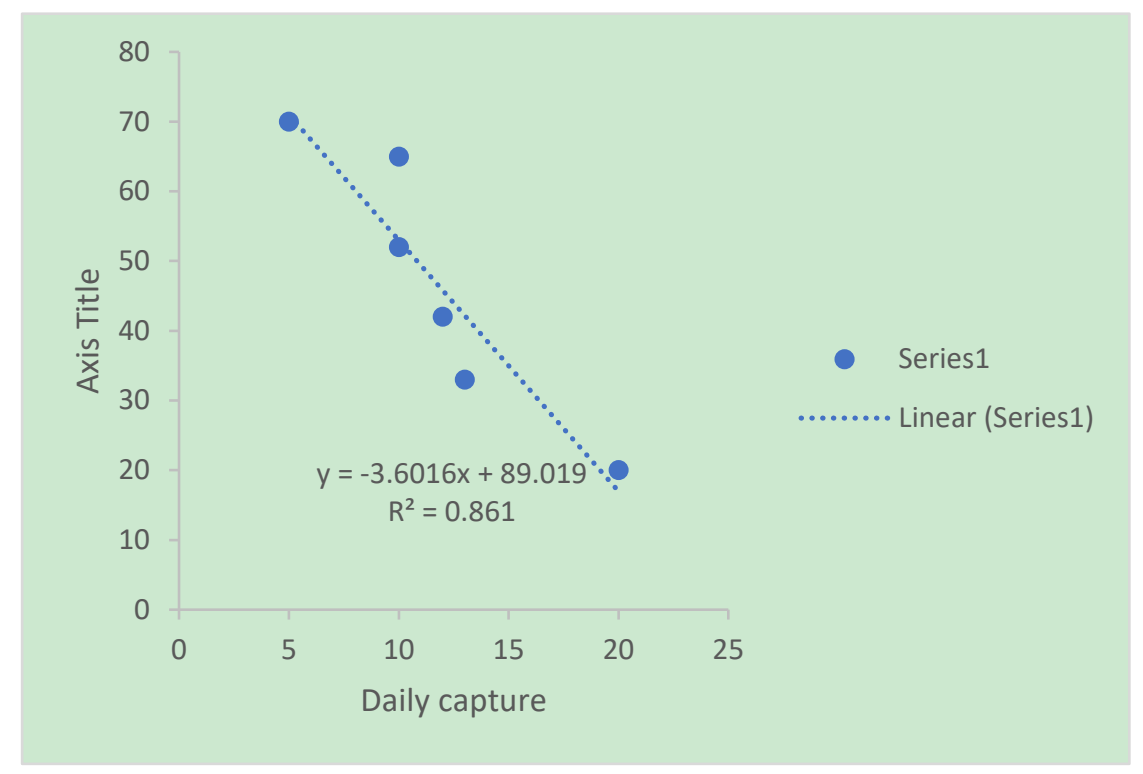

Fig. No.2 .Estimated population of (Mus musculs)

The estimated population of (Mus musculus) by regression analysis was 80 and minimum was 25 .

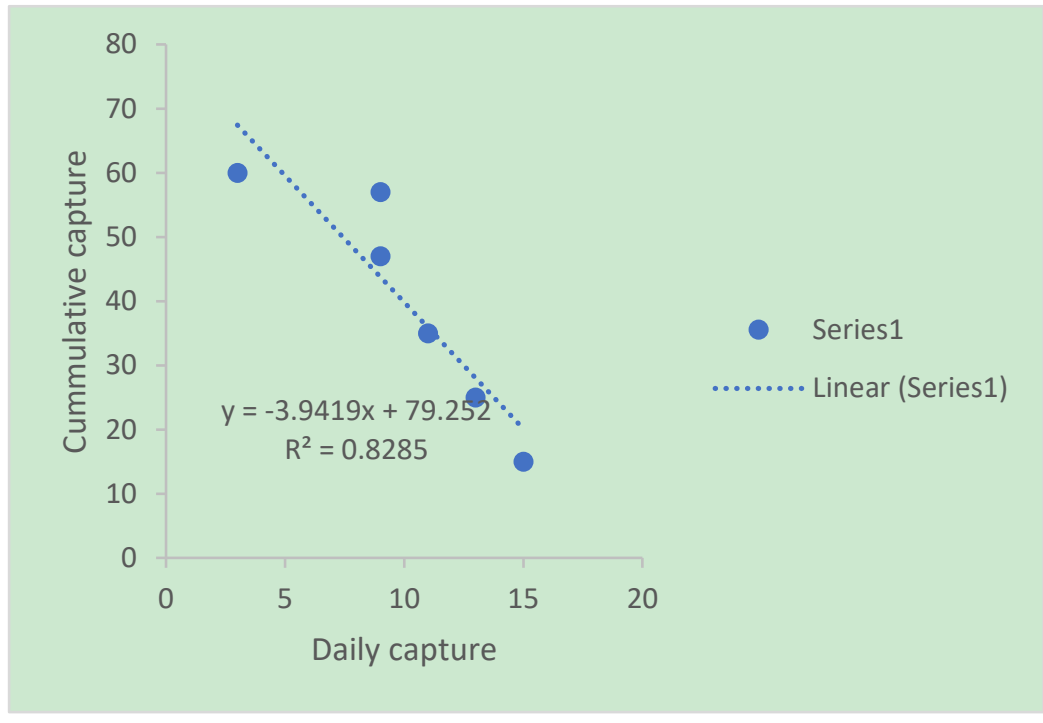

Fig. No.3 .Estimated population of (Apodemus rusigus)

The estimated population of (Apodemus rusigus) by regression analysis was 80 and minimum was 20 . 


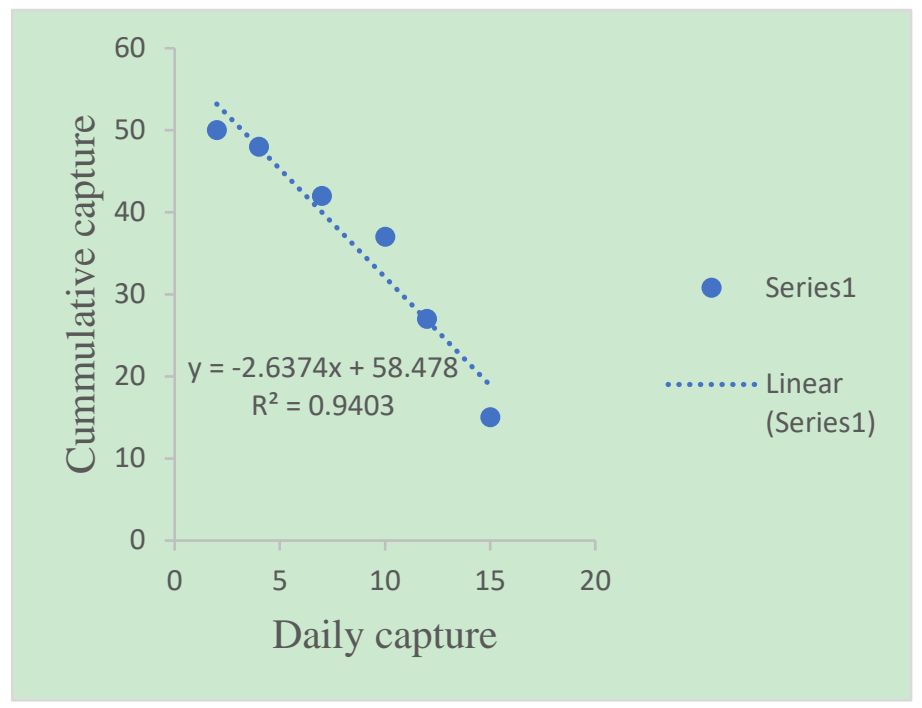

\section{Fig. No.4 .Estimated population of (Sorex plancip)}

The estimated population of (Sorex plancip) by regression analysis was 80 and minimum was 20 .

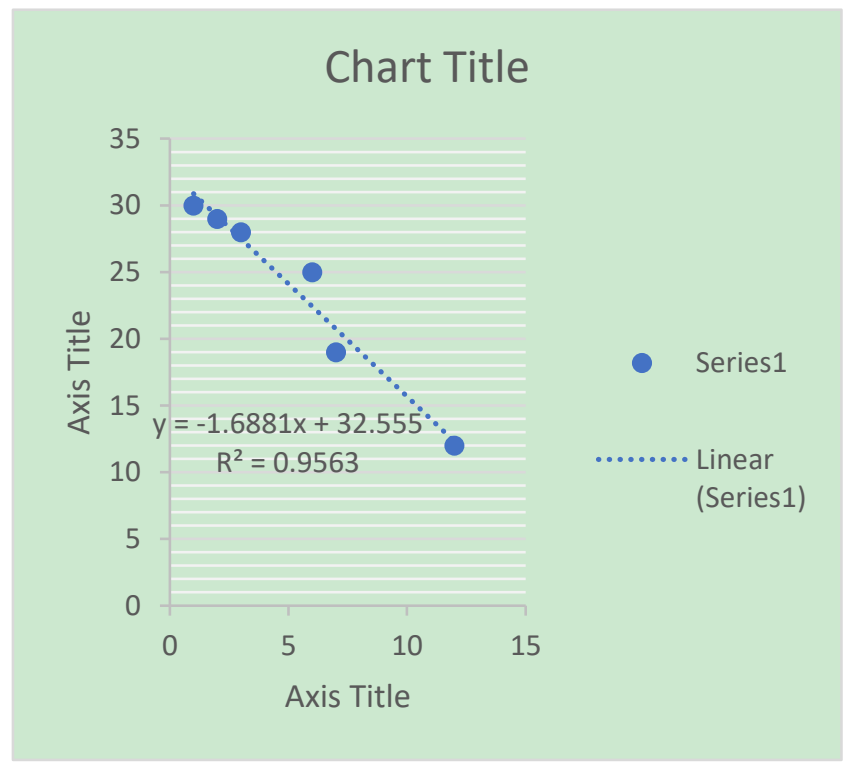

Fig. No.5 .Estimated population of (Rattus turkistanica)

The estimated population of (Ratus turkistanica) by regression analysis was 80 and minimum was 20 .

\section{Discussion}

The current study reports five species of small mammals, (Rattus rattus), house mouse (Mus 
musculus), Kashmir Field Mouse (Apodemus rusiges), one species of the Kashmir pigmy shrew, (Sorex planiceps) and one species of (Rattus turkistanica) and these findings are also reported by (Roberts, 1997) but location of these small mammalian in Himalayas are first time reported.

The species (Rattus rattus) was dominant in house dwelling in current study while the commensal nature (associated with human) is also described in number of studies (Faiz et al 2015).The distribution of the species (Rattus rattus) in wild vegetation is also reported in lesser Himalayas by (Faiz et al 2020).

The species (Mus musculus) was second dominant in house dwelling in current study while the commensal nature (associated with human) is also described in number of studies (Faiz et al 2014).The distribution of the species (Mus musculus) in wild vegetation is also reported in lesser Himalayas by (Faiz et al 2020).

The species (Apodemus rusiges) was present in vicinity of house dwelling in current study while the distribution of the species (Apodemus rusiges) in wild vegetation is also reported in lesser Himalayas (Pir Punjal range) by (Faiz et al 2016) in Tolipir National Park. The species (Sorex planiceps) was present in vicinity of house dwelling in current study while the distribution of the species (Sorex planiceps) in wild vegetation is also reported in lesser Himalayas (Pir Punjal range) by (Faiz et al 2016) in Tolipir National Park. The species (Rattus turkistanica) was present in vicinity of house dwelling in current study while the distribution of the species (Rattus turkistanica) in wild vegetation is also reported in lesser Himalayas (Pir Punjal range) by (Faiz et al 2016) in Tolipir National Park.

\section{References}


Faiz, A . Fakhar-i-Abbas, Mehboob ul Hassan and Lariab Zahra Faiz Distribution and Abundance of Vertebrate Pests of Cultivated Maize and their Eco-Friendly Management in District Bagh, Azad Jammu and Kashmir, Pakistan. Vol. 52(1), pp 1-4, 2020.

Faiz A H and Fakhar-i-Abass. Mammalian diversity of Tolipir national park, azad Jammu and Kashmir, Pakistan. Vol. 48(4), pp. 1209-1212, 2016.

Faiz A H and Fakhar-i-Abass. Biodiversity of small mammals in farm houses in some rural villages of Pothwar (Punjab) Pakistan. 2015 j. Anim. Plant sci. 25 (3supp.2) page: 441-445

Brooks, J. E., E. Ahmad, I. Hussain, S. Munir and A. A Khan (1990). A training manual on vertebrate pest management. USAID/DWRC/PARC, Islamabad, Pakistan, pp. 206.

Duncan R. Sutherlandand Grant R.2003 Singleton Monitoring activity patterns and social interactions of small mammals with an automated event-recording system: wild house mice (Mus domesticus) as a case study. rodent biology and management. ACIAR Monograph No. 96, 564p

Fiedler, L.A. 1988. Rodent problems in Africa. In: Prakash I., ed., Rodent pest management. Boca Raton, Florida, CRC Press, 35-65.

Grzimek's Animal Life Encyclopedia, Volume 13: Mammals II ... ISBN: 9780787657895 Edition: 2

Wolf, J and P.W. Sherman, (2007). Rodent Societies: An ecological and evolutionary perspective. Chicago, University of Chicago press. $610 \mathrm{pp}$

Pradhan, M. S and S. S Talmale (2011). A Checklist of valid Indian rodent taxa (Mammalia: Rodentia) (updated till May, 2011-online version), 1-13pp

Pardini R., Faria D. \& Baumgarten J. 2000. Biological guidelines to conservation plans: theRestaUna Project and the Una Biological Reserve, South Bahia. In: Milano M.S. and Theulen V.(eds) II Congresso Brasileiro de Unidades de Conservac ã o - Anais - Volume II - TrabalhosTé cnicos. Rede Nacional Pro'Unidades de Conservac ã o, Campo Grande, Brazil, pp. 715-721

Schipper J, et al. (2008) The status of the world's land and marine mammals: Diversity, threat, and knowledge. Science 322(5899):225-230

Tobin, Mark E. and Fall, Michael W., "Pest control: rodents" (2004). USDA National Wildlife Research Center - Staff Publications. Paper 67. 